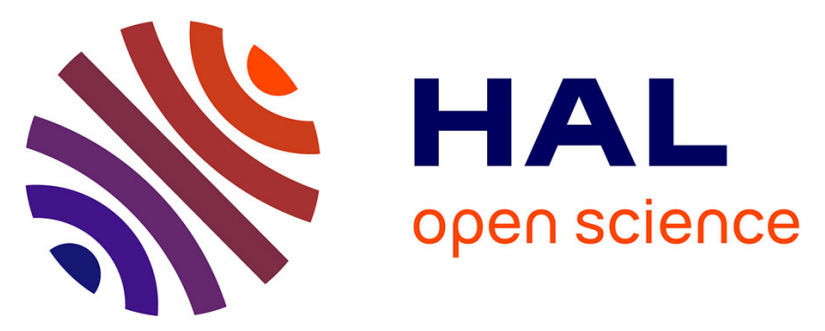

\title{
Win-win strategies for high beef quality, consumer satisfaction, and farm efficiency, low environmental impacts and improved animal welfare
}

\author{
Jean-François J.-F. Hocquette, Raphaëlle Botreau, Isabelle Legrand, Rod
} Polkinghorne, David William Pethick, Michel Lherm, Brigitte Picard, Michel Doreau, Claudia Terlouw

\section{To cite this version:}

Jean-François J.-F. Hocquette, Raphaëlle Botreau, Isabelle Legrand, Rod Polkinghorne, David William Pethick, et al.. Win-win strategies for high beef quality, consumer satisfaction, and farm efficiency, low environmental impacts and improved animal welfare. Animal Production Science, 2014, 54 (10), pp.1537-1548. 10.1071/AN14210 . hal-01190076

\section{HAL Id: hal-01190076 https://hal.science/hal-01190076}

Submitted on 1 Sep 2015

HAL is a multi-disciplinary open access archive for the deposit and dissemination of scientific research documents, whether they are published or not. The documents may come from teaching and research institutions in France or abroad, or from public or private research centers.
L'archive ouverte pluridisciplinaire HAL, est destinée au dépôt et à la diffusion de documents scientifiques de niveau recherche, publiés ou non, émanant des établissements d'enseignement et de recherche français ou étrangers, des laboratoires publics ou privés. 


\title{
Win-win strategies for high beef quality, consumer satisfaction, and farm efficiency, low environmental impacts and improved animal welfare
}

\author{
J. F. Hocquette $\mathrm{A}, \mathrm{B}, \mathrm{F}$, R. Botreau ${ }^{\mathrm{A}, \mathrm{B}}$, I. Legrand ${ }^{\mathrm{C}}$, R. Polkinghorne ${ }^{\mathrm{D}}$, D. W. Pethick ${ }^{\mathrm{E}}$,

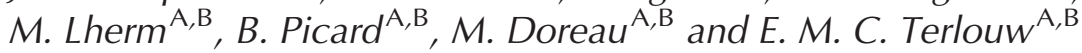 \\ AINRA, UMR1213, Recherches sur les Herbivores, F-63122 Saint Genès Champanelle, France. \\ ${ }^{B}$ Clermont Université, VetAgro Sup, UMR1213, Recherches sur les Herbivores, \\ F-63122 Saint Genès Champanelle, France. \\ CInstitut de I'Elevage, Service Qualité des Viandes, MRAL, 87060 Limoges Cedex 2, France. \\ D431 Timor Road, Murrurundi, NSW 2338, Australia. \\ ${ }^{\mathrm{E} S}$ chool of Veterinary and Life Sciences, Murdoch University, Murdoch, WA 6150, Australia. \\ ${ }^{F}$ Corresponding author. Email: jean-francois.hocquette@clermont.inra.fr
}

\begin{abstract}
Meat quality includes intrinsic qualities (the characteristics of the product itself) and extrinsic qualities (e.g. animal health and welfare, environmental impacts, price). There is still a high level of variability in beef palatability, which induces consumer dissatisfaction. We also observe a general trend towards an increasing importance of healthiness and safety (intrinsic) and environmental issues and animal welfare (extrinsic). Most grading systems describe carcasses using only animal traits (e.g. weight, conformation, fatness, animal age and sex). In North American and Asian countries, emphasis has been put on maturity and marbling. The European system is mainly based on yield estimation. The Meat Standards Australia grading scheme, which predicts beef palatability for each cut, proved to be effective in predicting beef palatability in many other countries. Some genetic markers are available to improve beef quality. In addition, gene and protein expression profiling of the bovine muscle revealed that the expression level of many genes and the abundance of many proteins may be potential indicators of muscle mass, tenderness, flavour or marbling of meat. The integration of all these parameters is likely to predict better beef palatability. The integration of extrinsic qualities in the prediction model increases the difficulty of achieving a global evaluation of overall meat quality. For instance, with respect to environmental issues, each feeding system has its own advantages and disadvantages. Despite this, win-win strategies have been identified. For example, animals that were less stressed at slaughter also produced more tender meat, and in some studies the most economically efficient farms had the lowest environmental impact. In other cases, there are trade-offs among and between intrinsic and extrinsic qualities. In any case, the combination of the different integrative approaches appears promising to improve the prediction of overall beef quality. A relevant combination of indicators related to sensory and nutritional quality, social and environmental considerations (such as e.g. carbon footprint, animal welfare, grassland biodiversity, rural development) and economic efficiency (income of farmers and of other stakeholders of the supply chain, etc.) will allow the prediction of the overall quality of beef mainly for consumers but also for any stakeholder in the supply chain.
\end{abstract}

Additional keywords: data combination, palatability, prediction model, social expectations.

Received 12 March 2014, accepted 18 June 2014, published online 19 August 2014

\section{Introduction}

Despite a great deal of research and effort by the industry to control beef quality, its variability remains high. The inability of the supply chain to guarantee consistent good-quality beef to the consumer is one reason for dissatisfaction. Consumers' beef purchase intentions depend mainly on beef eating quality attributes, which are a combination of consumers' taste, tenderness and juiciness assessments (reviewed by Hocquette et al. 2014). Consumers generally welcome the idea of a beef eating-quality guarantee, but, to do so, we need the tools to deliver a reliable outcome in a commercial setting (Verbeke et al. 2010).
Consumers also have increasing concerns for traceability, safety and healthiness due to different safety crises (bovine spongiform encephalopathy, foot and mouth disease, etc.). Statements from the medical profession that beef meat may be a risk for the development of various diseases in humans, despite existing strategies to enhance nutritional value of beef such as increasing omega-3 fatty acids, add to these concerns (reviewed by Doreau et al. 2011). All these factors have induced a decrease in beef consumption in most developed countries, and this trend was amplified by media campaigns (illicit trading and use of hormones, safety crisis, emphasis on environmental degradation 
by livestock, etc.). Consumers' dissatisfaction was further amplified by economic and societal evolutions (industrialisation, intensification of agriculture and urbanisation), which have delivered cheaper meat alternatives (chicken, pork) (reviewed by Pethick et al. 2011) and also induced a disconnection between citizens and consumers on one hand, and farmers and farm animals on the other hand. As a consequence, urban citizens and consumers have more and more concerns related to animal welfare and environmental issues relative to beef production.

The problems mentioned above are resolvable. For example, Scollan et al. (2011) indicated that there were numerous synergies and win-win strategies to improve simultaneously beef quality, safety and carbon footprint as well as animal welfare. Science and innovation have a major role to play in helping the industry respond to societal and consumer concerns and expectations, and can contribute substantially to finding solutions for major challenges facing the beef industry. Unfortunately, transfer of knowledge and innovation from science to the industry is weak in the meat sector and needs to be strengthened to maintain its competitiveness (Troy and Kerry 2010).

In the first section of this review, recent progress to predict beef palatability (one major intrinsic quality criterion of beef) will be described based on the recent evolution of grading systems and more long-term research (in muscle biochemistry and genomics). The second section will deal with win-win strategies or trade-offs for extrinsic quality traits of beef (welfare, environmental, societal or economic issues) and intrinsic ones. In this section, examples of win-win strategies to enhance sensory traits (tenderness) while maximising animal welfare, farm efficiency and low environmental impacts will be described. The last section will suggest research priorities based on multicriteria analyses to develop integrative approaches aiming to respond to a range of demands of consumers and citizens while producing beef with enhanced palatability.

\section{Recent progress to predict beef quality}

\section{Grading systems: towards a global appraisal} of beef palatability

Grading has been developed to provide a common basis for the description of carcasses for pricing purposes and for use in trade for the transaction between livestock producers and meat processors. There are many carcass-based grading systems in the World depending on the country (reviewed by Polkinghorne and Thompson 2010). There is also a trend to move away from visual classification towards automated, non-destructive, non-invasive, objective, cost-effective, and accurate methods to assess carcass characteristics in the abattoir at line speed (reviewed by Craigie et al. 2012). Current carcass grading systems include several characteristics, such as carcass weight, and according to the system, sex, age or maturity of the animal, fatness, fat colour, and carcass conformation. The EUROP grid of carcass classification was developed in the common EU market (Council Regulation 1234/2007). It is based on visually assessed scores for conformation and fat classes, which are combined to form a categorical description of the carcass. The EUROP grid is mainly based on yield estimation to pay producers, but it does not predict eating quality at the consumer level (Bonny et al. 2013).
In countries from Asia, America and Oceania, the carcass grading systems also include marbling and lean colour. USDA Quality Grades are used to predict the palatability of meat from a beef carcass, using carcass physiological maturity and marbling. USDA 'Prime' is the top grade of beef available on the market. 'Prime' has the most amount of marbling, which is supposed to guarantee taste, tenderness and juiciness. 'Choice' is typically lower in cost and quality, but still provides good beef. USDA 'Select beef' is the lowest grade of beef. It is much leaner than 'Prime' or 'Choice'.

In reality, most of the current carcass grading and classification schemes are indicators of cattle finishing or fatness and/or meat yield rather than indicators of the real beef palatability at the consumer level (reviewed by Polkinghorne and Thompson 2010). Therefore, consumer grading schemes were set up to predict more or less accurately consumer satisfaction with ready-to-use products. Depending on perception of consumers' expectations, different strategies were developed based on tradition, image, geographical origin or palatability. In Europe, consumers have to make a choice between official labels and non-official ones. The former identify a superior quality based on image and palatability (e.g. 'Label Rouge' in France), on environmental quality (e.g. organic farming), on tradition (e.g. 'TSG' meaning traditional speciality guaranteed) or associated to origin (e.g. 'PDO' for protected designation of origin and PGI for protected geographical indication). Non-official labels include certified products differentiated from standard products by some specific characteristics or products highlighting a specific feature (such as meat produced from grass-fed animals or 'on-farm processed' or 'mountain produced'). There are in fact many beef schemes related to areas of geographical origin, brands, and/or breeds (for example, specialist Hereford or Aberdeen Angus beef and beef products). Generally, consumers have a positive perception of products with official labels, but they express a degree of misunderstanding on the real guarantees offered by the numerous labels (official or nonofficial) that exist in the market. The development of such schemes is based on the assumption that consumers attach great importance to taste, to the pleasure of eating, to preexisting know-how, to typical geographical areas where production takes place, to traditional gastronomy, and/or to sustainable development of agriculture. However, a high price for labelled products does not favour final purchase. This explains the relative success of non-official labels (or certified products), which are cheaper but with fewer guaranties compared with official labels (reviewed by Hocquette et al. 2012b). At least in France (Normand et al. 2009), no clear relationship was found between the price of beef at the market level and its real tenderness assessed by consumers. This means that consumers can find good beef at a low price or can be disappointed by expensive beef, which is not good for the development of the beef market.

In addition, consumers do not eat carcasses but portions of meat derived from muscles or cuts. Therefore, we can simply argue that any carcass-grading scheme will not be able to accurately predict palatability of cooked beef at the plate level. Highlighting this view is that muscle type and cooking method have a great impact on palatability (Thompson 2002) and that post-mortem factors (especially ageing) are very important for 
beef palatability compared with pre-mortem factors (Juárez et al. 2012). The development in Australia of the Meat Standards Australia (MSA) grading scheme to predict beef quality for consumers has been based on these principles. It predicts a palatability score (on a $0-100$ scale) for each cut $\times$ cooking method combination and according to different factors including ageing time (reviewed by Thompson 2002). The MSA success has been based on standardisation of the consumer evaluation protocols and on accumulation of large amounts of data over time that have been treated by rigorous statistical analyses in order to identify the main factors affecting beef palatability (reviewed by Polkinghorne and Thompson 2010). In this approach, assessment of quality (tenderness, flavour liking, juiciness, overall liking) is done by untrained consumers, and not by trained panellists, as in many global studies. The MSA approach has been tested successfully in many countries including South Korea, the USA, Japan, South Africa, New Zealand, Northern Ireland, the Irish Republic, Poland (for review, see Hocquette et al. 2014) and France (Legrand et al. 2013) (Fig. 1). Despite some minor differences that need to be taken into account in the prediction, consumers provide similar responses for the assessment of beef quality in all studied countries.

\section{Recent advances in biochemistry and genomics}

All the previous grading systems have been developed to satisfy consumers based on the intrinsic quality (e.g. palatability for the MSA approach) or the extrinsic quality (e.g. image, origin,
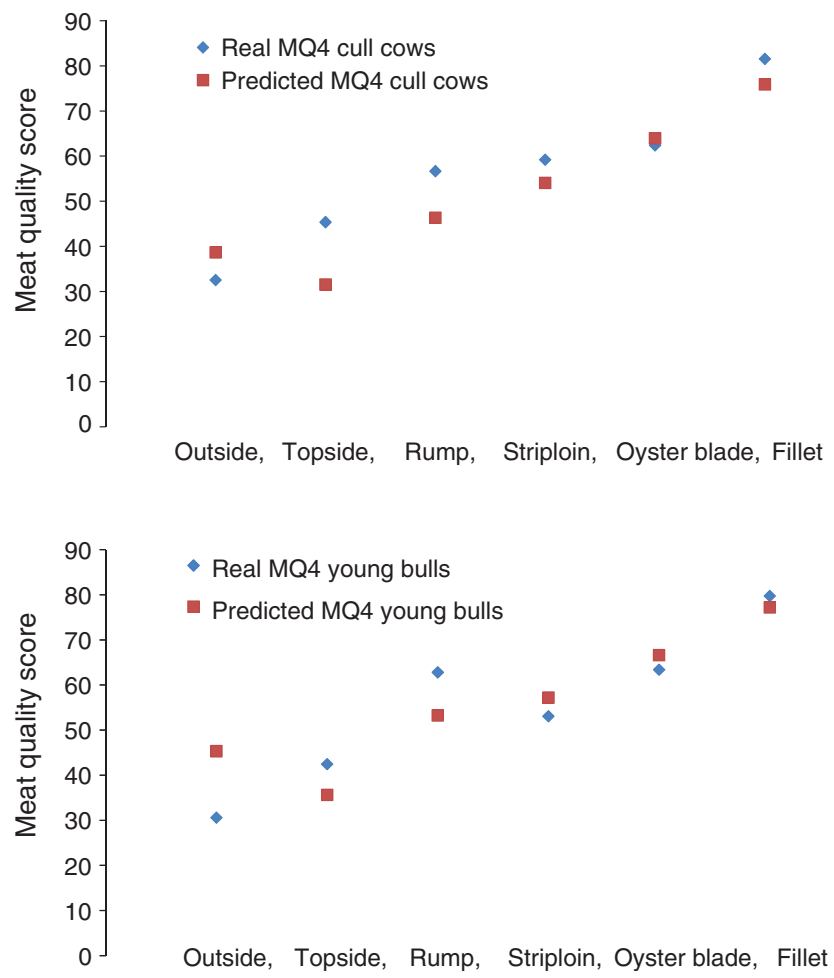

Fig. 1. Prediction of beef quality in France for cull cows and young bulls using the Meat Standards Australia (MSA) system. Meat quality score (MQ4) is indicated on a $0-100$ scale. Real MQ4 from consumer tests and predicted MQ4 from the MSA model are both indicated for each muscle (adapted from Legrand et al. 2013). tradition) of the products for consumers. However, prediction models can also be developed for other key players (i.e. other than consumers) who may be geneticists, producers or retailers (reviewed by Hocquette et al. 2014) to improve breeding strategy or adapt farming practices depending on animals' capacities. In that case, emphasis for modelling has been put on muscle biochemical characteristics and on the genes and proteins that determine these characteristics.

For several years, various functional genomic programs were conducted at national and international level to search for biomarkers of beef qualities. Some studies focussed on muscle and adipose tissue development, others on muscle hypertrophy, flavour or marbling (for reviews, see Cassar-Malek et al. 2008; Picard et al. 2011), but the most numerous studies concerned beef tenderness (Picard et al. 2012).

A major challenge for meat scientists around the world is to understand the variability in tenderness which is at the origin of a dissatisfaction of the beef consumers. For beef producers, it is of interest for breeding or finishing purposes to predict the ability of live animals to produce good meat, with specific attention towards tenderness. Today tenderness can be estimated only after slaughter, by sensory analysis tests and/or mechanical measurements. Thus, the Beef sector is looking for biological or molecular indicators that would identify live animals with desirable quality attributes, in order to direct them towards the most appropriate production system. Meat tenderness is a multifactorial trait that has been extensively studied worldwide. However, although some biochemical factors are well known and several Quantitative Trait Loci (QTLs) for tenderness were detected, the control of tenderness variability remains a major challenge.

Several studies report QTL detection of tenderness sensorial score or Warner-Bratzler shear force (for a review, see Hocquette et al. 2008). For example, single-nucleotide polymorphisms in the CAPN1 and CAST genes were identified and significantly associated with shear force. Markers in the CAPN1 and CAST genes are currently integrated into marketed genetic tests. Several validation studies confirmed that polymorphisms in both genes were associated with differences in tenderness but with relatively modest substitution effects ranging from 0.1 to 0.4 phenotypic standard deviation (for review, see Picard et al.2012). Allais et al. (2011) demonstrated that single-nucleotide polymorphisms in these two genes were not consistently associated with tenderness in the three main French beef breeds (Limousin, Charolais, Blonde d'Aquitaine). Besides these two genes, several studies revealed associations between tenderness and other candidate genes: $H G D, C A P N 3, P O M C, C E B P A, G H R$, and PPARG. However, none appeared markedly significant. The strategy based on the search for a limited number of candidate genes that would explain most of the variability of meat quality has to date been unsuccessful.

Therefore, genomic analyses have been conducted to better understand processes underlying tenderness or to provide biological markers predicting tenderness (Cassar-Malek et al. 2008; Picard et al. 2012). Comparative transcriptomic and proteomic analyses, conducted on bovine muscles with low or high tenderness scores estimated by sensory analysis and/or mechanical measurements, bring up a list of potential biological markers that may be used as phenotypic biomarkers 
to predict the 'tenderness potential' of an animal or a carcass (for review, see Hocquette et al. 2008). The main results obtained in the Longissimus thoracis (LT) from French beef breeds have demonstrated that in more tender LT, the slow oxidative-type proteins were more abundant. These proteins include, for example, $\alpha$ Enolase, an isoform of troponin $\mathrm{T}$ slow, slow isoforms of myosin-light chains, the creatine kinase $\mathrm{M}$, and the mitochondrial protein NADH-ubiquinone oxidoreductase. Other experiments of the literature led to similar conclusions about the relationship between oxidative metabolism and tenderness in LT muscle (Picard et al. 2011, 2012). Consistent with this view, proteins related to glycolytic metabolism (such as phosphoglucomutase (PGM), lactate dehydrogenase B (LDH B), triphosphate isomerase, glyceraldehyde-3-phosphate dehydrogenase (GAPDH), the fast troponin T (TnTf) isoforms and the $\beta$ enolase) were less abundant in the more tender LT. Several proteins involved in calcium metabolism were also identified as positive markers for tenderness. For example, the amount of Parvalbumin peptides is considerably increased in tender muscle (Picard et al. 2012). The calcium cycle proteins seem strongly involved in meat tenderness, in connection with the important role of calcium in meat ageing. Accordingly, Bjarnadottir et al. (2012) recently found a relationship between Annexin 6, involved in release of calcium, and tenderness. A set of proteins of the family of heat shock proteins (Hsp) was revealed as markers of tenderness at the transcript or protein level in different experiments. For example, it was shown that gene expression $D N A J A 1$ protein (Hsp40) was an appropriate indicator of meat toughness of Charolais young bulls (for a review, see Cassar-Malek et al. 2008). According to the hypothesis of Ouali et al. (2013), the antiapoptosis DNAJA1 could slow down the process of cell death during the early stages of transformation of muscle into meat, and therefore induce more toughness. Other family members (Hsp27, Hsp20, $\alpha B$-crystallin, Hsp70) were also identified as markers of tenderness in several programs (Ouali et al. 2013). Other results revealed also a role in tenderness of proteins involved in oxidative stress such as super-oxide dismutase and Peroxiredoxin 6 (for a review, see Picard et al. 2012).

From this list of protein markers of beef tenderness, a bioinformatic analysis was conducted in order to have a better understanding of the biological functions involved in tenderness and the interactions between all these proteins (Guillemin et al. 2011). This work highlighted cellular pathways strongly involved in tenderisation processes: apoptosis, HSP functions and oxidative stress resistance.

In order to analyse biomarkers on a large number of samples simultaneously, new molecular tools were developed (Fig. 2). A DNA chip with specific genes involved in muscle biology or beef quality was developed to study simultaneously the expression of $\sim 3000$ genes (Hocquette et al. 2012a). At the protein level, a dot-blot tool was developed for the measure of relative abundance of proteins (Picard et al. 2011). This

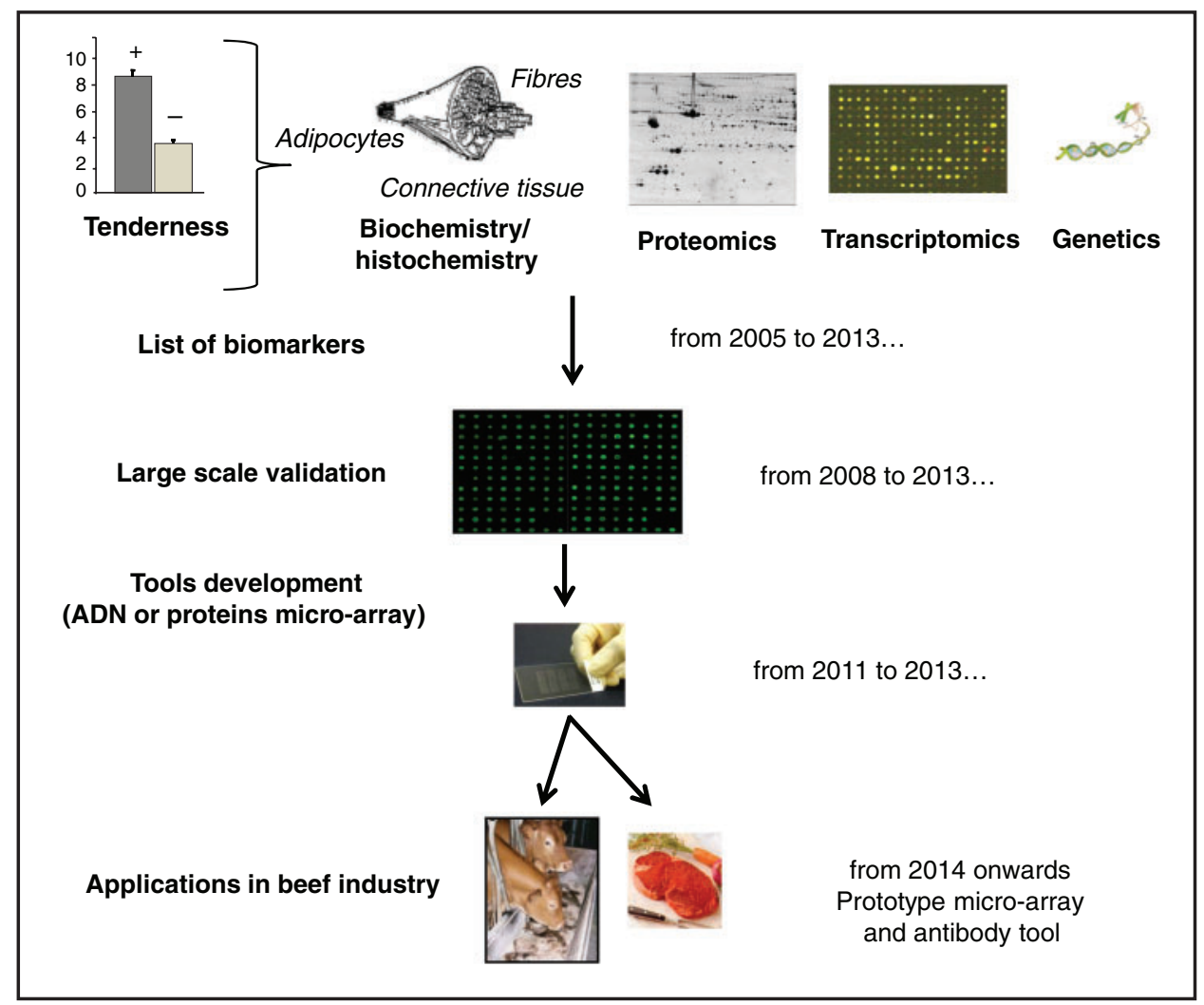

Fig. 2. Overall strategy of genomics research to improve the prediction of beef quality including tenderness, flavour and marbling. 
immunological tool allows measuring the relative abundances of many proteins for several muscle samples simultaneously. These tools are currently used in several experiments with different breeds and muscles in order to establish predictive equations of beef tenderness from the relative abundance of a list of 24 proteins. The preliminary results showed that regression equations predicting tenderness were specific for breed (Picard et al. 2012) or animal groups that differ by husbandry factors (Hocquette et al. 2012a).

This strategy of research of biomarkers of quality is developing worldwide for several qualities and for the study of the effect of animal type and management factors on the expression of the biomarkers (for a review, see Picard et al. 2011). However, the general observation is that the ability of gene markers, gene expression or protein levels to predict tenderness is generally breed-specific, muscle-specific or specific of animal groups, making it difficult to develop generic equations for the prediction of tenderness across a broad population of beef cattle in a commercial context. This is in line with biochemical studies that demonstrated that the prediction of beef tenderness from muscle characteristics (collagen amount and solubility, size, type and metabolism of muscle fibres) depends on muscle and animal type (young bulls, cows, etc) (Chriki et al. 2013). However, marbling or intramuscular fat level have a phenotypic and genotypic association with tenderness, which make them simple and relevant markers for tenderness although the underlying mechanisms are not completely understood. It is thought to be associated with lowering connective tissue toughness in both sheep and cattle (Reverter et al. 2003; Mortimer et al. 2014). Unfortunately, as for biomarkers of tenderness, none of the known biomarkers to predict the ability of livestock to produce marbled beef are omnipotent.

From a genetic point of view, this may not be such a problem with the advent of genomic selection, which is based on markers that cover the whole genome. Therefore, the whole genetic variance is potentially explained by all these markers which can be analysed simultaneously at a relatively low cost using commercially available DNA chips for genotyping. This new strategy is changing the agendas and organisation of private companies, as genomic selection is redesigning animal breeding programs. However, genomic selection requires accurate recording of phenotypes on large reference populations. Therefore, phenotyping is becoming the next challenge in animal science (for a review, see Hocquette et al. 2012c), and especially in meat science. This is the reason why ontology programs have been designed. Similarly, standardised methods have been set up to analyse, in a repetitive manner, sensory traits of beef (for a review, see Polkinghorne and Thompson 2010).

\section{Win-win strategies or trade-offs for extrinsic and intrinsic quality traits of beef}

Win-win strategies for sensory quality and welfare issues

Consumers demand beef of good quality while animal welfare is becoming increasingly important for citizens. Therefore, beef palatability and animal welfare issues during rearing and at slaughter need to be simultaneously addressed.
It has long been known that slaughter conditions may have a significant impact on meat quality. For example, earlier studies found that in bulls, aggressive behaviour caused an increase in Dark, Firm, Dry (DFD) meat. The underlying mechanisms are well described: following slaughter, muscle glycogen is degraded, but in the absence of oxygen and blood circulation, protons and lactate accumulate locally in the muscle, causing a $\mathrm{pH}$ decline. This decline is initially fast, then slows and stabilises at a value called ultimate $\mathrm{pH}$, reached $\sim 24 \mathrm{~h}$ post mortem. The extent of $\mathrm{pH}$ decline depends principally on muscular glycogen reserves before slaughter. Increased activity and associated psychological stress during the hours preceding slaughter reduces muscle glycogen reserves and may result in high ultimate $\mathrm{pH}$ which is the cause of DFD meat. DFD meat has adverse qualities in terms of colour, microbiological development and shelf life, water-holding capacity and meat touch (sticky touch), taste and juiciness. Consequently, much effort was undertaken to improve slaughter conditions in order to limit production of meats with these quality defects. Animal stess should thus be reduced from the farm to the slaughter house including loading in trucks, transportation, unloading, and waiting in individual boxes before slaughtering. Some guidelines are now available (for instance, the French standard NF V46001 of December 1996).

While the phenomenon of high ultimate $\mathrm{pH}$ was well known in cattle, for many years little attention was paid to possible variations between cattle in early post-mortem $\mathrm{pH}$ decline. The initial rate of $\mathrm{pH}$ decline depends on the metabolic activity of the muscle during the early post-mortem period. Variations in $\mathrm{pH}$ decline were noticed nearly 20 years ago in calf carcasses and may represent an important explanatory factor of colour variation, sometimes more important than muscle haem iron contents (mainly linked to feeding) in some specific muscles (e.g. psoas major: Guignot et al. 1992). Only recently it was established that this phenomenon can also be observed in older cattle. Increased stress levels in Normand cows or bulls of different breeds, indicated by faster heart rates only a few minutes before slaughter, are accompanied by a faster $\mathrm{pH}$ decline, explaining $36-50 \%$ of the variability in the rate of $\mathrm{pH}$ decline between individuals (Bourguet et al. 2010; Terlouw et al. 2012). Stress before slaughter not only influences early $\mathrm{pH}$ decline, but also sensory beef quality. Warner et al. (2007) found that the use of electric prodders was associated with lower sensory ratings, including tenderness, by consumers. Gruber et al. (2010) also showed a relationship between elevated blood lactate concentration (at bleeding) and reduced tenderness, suggesting that acute stress just before slaughter can negatively influence tenderness. In another experiment, cows slaughtered with minimal stress ( $7 \mathrm{~min}$ transport) produced significantly more tender meat than cows slaughtered after a stress treatment (48 min transport combined with a physical and emotional stress treatment: Bourguet et al. 2010). These effects of stress on tenderness were not directly related to rate of $\mathrm{pH}$ decline or ultimate $\mathrm{pH}$ (Terlouw et al. 2012). The biochemical mechanisms underlying beef tenderness appear to depend on the slaughter conditions. When slaughtered with minimal stress, cows that had relatively low heart rates on the farm just before being loaded onto the lorry produced meat with relatively high tenderness (Fig. 3). When slaughtered after the stress treatment, meat 


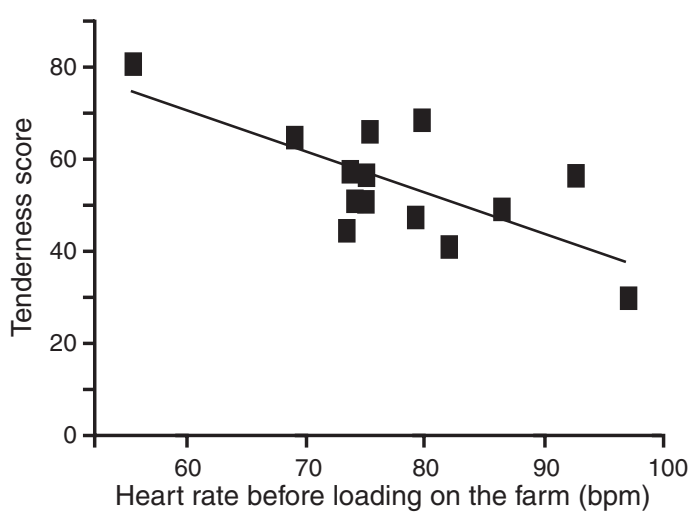

Fig. 3. Tenderness score (values from $0-100$, higher scores indicating increased tenderness) rate was negatively correlated $(r=-0.71, P=0.004)$ with heart rates (beats per minute, $\mathrm{bpm})$ just before loading the cows $(n=14)$ in the lorry.

was toughest in cows having relatively low levels of oxidative metabolism in the muscle immediately after slaughter (Terlouw et al. 2012).

Stress at slaughter depends not only on the slaughter conditions, but also on the stress reactivity of the animals. When subjected to several reactivity tests during rearing, it was possible to identify cows that were more likely to be reactive to the slaughter procedure, in terms of reduced tenderness (Terlouw et al. 2012).

Overall, results indicate that stress reactivity measured during rearing may predict stress reactions of cattle during the slaughter period. Stress reactions at slaughter have a potentially strong impact on technical and sensory meat quality indicators, including $\mathrm{pH}$ decline, ultimate $\mathrm{pH}$, colour, water-holding capacity, shelf-life, juiciness, taste and probably tenderness. The above results show that although the underlying mechanisms are sometimes not yet entirely known, meat quality may be significantly improved if at slaughter stress levels of the animals are kept low. Today, efforts continue to improve slaughter procedures. The selection of animals with a very low reactivity to stress is sometimes suggested and may contribute to reduce stress at slaughter but has its limits. The reason is that some stress reactivity is necessary for survival as it allows adaptation to a changing environment. For example, a very placid animal would not attempt to escape from danger and would also be very difficult to be driven forwards by humans. In addition, certain physical characteristics considered advantageous for breeding purposes may be genetically linked to stress reactivity.

In conclusion, limiting stress at slaughter, particularly by improving slaughter procedures, would be beneficial for animal welfare and for meat quality and therefore represents a win-win strategy.

\section{Win-win strategies and trade-offs between environmental} value and other beef quality traits

There are very few examples of direct interaction between intrinsic beef quality and environmental value. Palatability depends for a great part on non-nutritional factors, although good nutrition prior to slaughter is important, whereas environmental value is mostly related to animal feeding and farming systems. In Australia, it was shown that a high continuous growth rate from birth improves meat palatability (reviewed by Thompson 2002) and may simultaneously improve environmental/feed efficiency outcomes due to a reduction in the proportion of food used in maintenance. Nutritional quality of beef from a human health perspective also depends on animal feeding and could thus be related to environmental value. This has been shown for the enrichment of the animal diet with omega-3 fatty acids. Supplementation of finishing diets with linseed results not only in a higher content of omega-3 fatty acids in meat (Doreau et al. 2011) but also a decrease in methane emission per kilogram of liveweight gain (Eugène et al. 2011). However the positive effect on the environment is of lower extent when the whole beef system is considered, owing to a partial compensation by an increase in other greenhouse gases than methane, and because the finishing period represents only $10 \%$ of the total greenhouse gas emissions (Nguyen et al. 2012).

Grass feeding is considered to provide beef of good quality because it is rich in omega-3 fatty acids and produced in a natural way. Even if the relationship between grass feeding and good palatability is not demonstrated, this mode of production is treated as such by many European consumers, leading to quality labels associated with origin, or to specific types of production such as organic farming. The positive externalities of grass feeding mainly concern natural grasslands in mountain areas or other non-arable areas. Contrary to farming in arable areas using temporary grasslands, interspersed with broadacre cropping, natural grasslands and associate structures (hedges, banks, ditches) allow the maintenance or the increase of plant biodiversity (Dumont and Tallowin 2011). In addition, plant biodiversity can have a positive effect on animal health (Farruggia et al. 2008). Moreover, in most cases, carbon sequestration in soils under natural grassland compensates in part for the greenhouse gas emissions (Soussana et al. 2010). Beef production based on grass in mountains or other areas with a limited production potential leads to a better quality of water due to a limited use of fertilisers and pesticides, and contributes to the vitality of rural territories because other agricultural production is not possible or less profitable (Peyraud 2011). Such ecosystem services are seldom taken into account in environmental evaluations of beef farming because a unique methodology is not shared by the scientific community (e.g. case of biodiversity or territorial management) or because reliable data are not available (e.g. case of carbon sequestration, of which the extent is extremely variable). It is sometimes argued that the use of natural grasslands for beef production requires large soil area per kilogram of meat in a world where land occupation is a major issue, but these areas generally do not compete with crops for human food or for other animal products. In countries such as Australia, South Africa and the western USA there is a huge area of land that cannot be cropped and where grassland is the only possible production base. Ruminants alone can convert large quantities of poorquality herbage unsuitable for humans into a highly nutritious energy- and protein-dense human food.

When considering extrinsic qualities of beef, it is mandatory to be very careful regarding trade-offs between criteria, as shown by Doreau et al. (2013) when considering all aspects of livestock 
sustainability. For example, in the case of environmental impacts, a comparison between a feedlot-type high-concentrate diet and diets based on maize silage or hay in finishing bulls, which differed in liveweight gain, resulted in a much lower emission of methane for the high-concentrate diet, but a lower difference between diets when all greenhouse gases are considered (Table 1); energy use is lowest with the maize silage diet whereas eutrophication and acidification potential are lowest with the hay diet. The concentrate diet was more risky for animal health while the maize silage diet produced the highest gross margin for the farmer (Mialon et al. 2013). For the criterion of human nutritional quality, such as fatty acid composition of muscle, this study shows that the hay diet led to more beneficial fatty acids compared with the concentrate diet. So, in conclusion, there are examples of win-win strategies existing between the extrinsic qualities, but none on all the issues simultaneously.

A recent analysis of beef farms in French grassland areas with a limited production potential (Veysset et al. 2014, and unpubl. data) was done to conduct a joint environmental impact assessment and economic results of meat cattle production systems from commercial farms. It was considered here that greenhouse gas (GHG) emissions and fuel consumption of non-renewable energy were environmental indicators (among others). For each farm belonging to a known breeding network (i.e. for which data structure, technical and economic results were available), GHG emissions and consumption of non-renewable energy have been calculated using a methodology adapted to French farming systems (Bochu 2002).

The 59 farms (169 ha on average) were specialised beef cattle and/or mixed farming-beef cattle enterprises located in the Charolais basin (central France), highly specialised with large low-intensity operations. The main forage area occupies, on average, $84 \%$ of the Utilised Agricultural Area (UAA); $16 \%$ of the UAA was devoted to cash crops that were largely selfconsumed by the herd. With, on average, 171 livestock units (LU), the stocking rate was $1.21 \mathrm{LU} /$ ha of forage area. These farms produce mainly lean animals. Over $60 \%$ of the young males (9-13 months) were sold to specialised feeders in Italy for the Italian market. According to grassland orientation and relatively low stocking rate, mineral nitrogen fertilisation was quite low. The average gross GHG emissions are $12.8 \mathrm{~kg}$ $\mathrm{CO}_{2}$ eq/pound of live meat (kg live weight, lw). The major contributors to $\mathrm{GHG}$ was $\mathrm{CH}_{4}$ (66\% of emissions), followed by $\mathrm{CO}_{2}(19 \%)$ and $\mathrm{N}_{2} \mathrm{O}(15 \%)$. Enteric fermentation accounted for $82 \% \mathrm{CH}_{4}$ and $54 \%$ of total emissions. Manure management (storage building, spreading) represented $16 \%$ of $\mathrm{CH}_{4}$ and $40 \%$ of $\mathrm{N}_{2} \mathrm{O}$. Excreta (faeces and urine) at grazing and fertiliser application accounted for $39 \%$ and $20 \%$ of $\mathrm{N}_{2} \mathrm{O}$ emissions, respectively.

Table 1. Performances, nutritional quality, welfare, environment and economic indicators for three contrasted systems of bull fattening, based on hay (H), maize silage (MS) and concentrate (C)

Data are from Mialon et al. (2013), four primary publications cited in this latter paper, and unpublished data. Values followed by different letters are significantly different from each other at $P=0.05$

\begin{tabular}{|c|c|c|c|}
\hline \multirow[t]{2}{*}{ Indicator } & \multicolumn{3}{|c|}{ Experimental diet } \\
\hline & $\mathrm{H}^{\mathrm{A}}$ & $\mathrm{MS}^{\mathrm{A}}$ & $\mathrm{C}^{\mathrm{A}}$ \\
\hline \multicolumn{4}{|c|}{ Performances } \\
\hline BW gain $(\mathrm{kg} /$ day $)$ & $1.49 \mathrm{~b}$ & $1.71 \mathrm{ab}$ & $1.86 \mathrm{a}$ \\
\hline Feed efficiency (kg BW gain/MJ $\mathrm{NE}_{\mathrm{f}}^{\mathrm{B}}$ intake) & 84.8 & 90.4 & 87.4 \\
\hline Carcass fat $(\mathrm{kg} / \mathrm{bull})$ & $36 b$ & $48 \mathrm{a}$ & $41 \mathrm{ab}$ \\
\hline \multicolumn{4}{|c|}{ Meat nutritional quality } \\
\hline Saturated FA ( $\%$ total FA) & $40.1 \mathrm{~b}$ & $44.1 \mathrm{a}$ & $39.1 \mathrm{~b}$ \\
\hline n-6 FA : n-3 FA ratio & $7.28 \mathrm{c}$ & $8.27 \mathrm{~b}$ & $13.91 \mathrm{a}$ \\
\hline \multicolumn{4}{|c|}{ Animal welfare } \\
\hline Rumen average $\mathrm{pH}$ as index of digestive discomfort & $5.8 \mathrm{a}$ & $6.1 \mathrm{a}$ & $5.5 \mathrm{~b}$ \\
\hline \multicolumn{4}{|c|}{ Environment ${ }^{\mathrm{C}}$} \\
\hline Greenhouse gases emission ${ }^{\mathrm{D}}$ (kg CO 2 eq/kg BW gain) & 4.56 & 4.74 & 3.65 \\
\hline of which enteric methane ( $\mathrm{kg} \mathrm{CO}_{2}$ eq/kg BW gain) & $3.33 \mathrm{a}$ & $3.81 \mathrm{a}$ & $1.56 \mathrm{~b}$ \\
\hline Eutrophication potential ( $\mathrm{g} \mathrm{PO}_{4} \mathrm{eq} / \mathrm{kg}$ BW gain) & 16.5 & 19.0 & 21.5 \\
\hline Acidification potential ( $\mathrm{g} \mathrm{SO}_{2}$ eq $/ \mathrm{kg} \mathrm{BW}$ gain) & 31.3 & 38.1 & 29.4 \\
\hline Energy consumption (MJ/kg BW gain) & 18.7 & 13.0 & 19.7 \\
\hline Land use $\left(\mathrm{m}^{2}\right.$. year $/ \mathrm{kg}$ BW gain $)$ & 11.7 & 4.5 & 4.6 \\
\hline of which arable land (m².year/kg BW gain) & 3.4 & 4.5 & 4.6 \\
\hline \multicolumn{4}{|c|}{ Economy $^{\mathrm{C}}$} \\
\hline 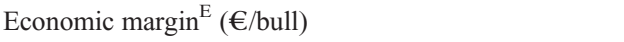 & 231 & 305 & 261 \\
\hline $\begin{array}{l}{ }^{A} H: 44 \% \text { permanent grassland hay and } 56 \% \text { concentr } \\
\text { concentrates and } 8 \% \text { straw. } \\
{ }^{\mathrm{B}} \text { Net energy for fattening, calculated using French feedi } \\
{ }^{C^{2}} \text { No statistics can be performed on results of life cycle a } \\
{ }^{\mathrm{D}} \text { Including carbon sequestration by grasslands. }\end{array}$ & $\begin{array}{l}\% \text { maiz } \\
\text { d on ec }\end{array}$ & $\begin{array}{l}42 \% \text { c } \\
\text { lits. }\end{array}$ & C: $92 \%$ \\
\hline
\end{tabular}


Overall, the animals were responsible for $78 \%$ of total emissions (rumination, manure), inputs for $15 \%\left(\mathrm{CO}_{2}\right.$ from the energy needed to manufacture and transport inputs, and $\mathrm{N}_{2} \mathrm{O}$ related to fertiliser application) and direct energy use (fuel, lubricants, electricity) on the farm is responsible for only $5 \%$ of gross GHG emissions.

These gross GHGs are offset up to $21 \%$ by storing carbon from the dynamic storage/retrieval in grasslands and croplands (Soussana et al. 2010), which represents 38\% of enteric methane. The net GHG emissions then averaged $10.06 \mathrm{~kg} \mathrm{CO}_{2}$ $\mathrm{eq} / \mathrm{kg} \mathrm{lw}$.

These averages mask considerable variability of economic and environmental outcomes. Gross GHG emissions range from 9.5 to $21.1 \mathrm{~kg} \mathrm{CO} 2 \mathrm{eq} / \mathrm{kg} \mathrm{lw}$; that is, a difference of $122 \%$ between the extremes. Fifty percent of farms are between 11.6 and $13.6 \mathrm{~kg} \mathrm{CO}$ eq with $17 \%$ difference between the first and third quartiles. Net emissions vary from 7 to $15 \mathrm{~kg} \mathrm{CO}$ eq $/ \mathrm{kg}$ lw. There was a negative correlation between net GHG emissions and productivity based on weight of beef produced per hectare $(r=-0.54)$, but less than that observed between gross emissions and productivity. Gross GHG emissions were independent of the stocking rate while net emissions were positively correlated $(r=0.32)$ due to carbon sequestration, partly compensating for emissions. We also observe that the net GHG emissions by $\mathrm{kg} \mathrm{lw}$ are positively correlated with the size of the farm: $r=0.32$ and $r=0.37$ respectively with the number of LU and the number of hectares of UAA. Specialisation of the operation also affects GHG emissions, with specialist beef production farms emitting less net GHG/ $\mathrm{kg} \mathrm{lw}(r=-0.27)$.

Gross bovine margin also varies from $150 € / \mathrm{LU}$ to $550 € / \mathrm{LU}$ and, importantly, varied showing a significant negative correlation with net emissions (Fig. 4). That is, the most productive efficient systems, i.e. maximising meat production by minimising the use of inputs, combined with strong economic performance (product with more controlled charges), had the lowest net emissions per unit of output - a clear win-win. However, this is not always the case: for instance, for a gross margin of $350 € / \mathrm{LU}$, net $\mathrm{GHG}$ emissions range from 9 to $13.6 \mathrm{~kg} \mathrm{CO} \mathrm{CO}_{2} \mathrm{eq} / \mathrm{kg} \mathrm{lw}$, and for a net $\mathrm{GHG}$ emission of $12 \mathrm{~kg} \mathrm{CO}$ eq/kg lw, gross margin ranges from $200 € / \mathrm{LU}$ to $480 € / \mathrm{LU}$.

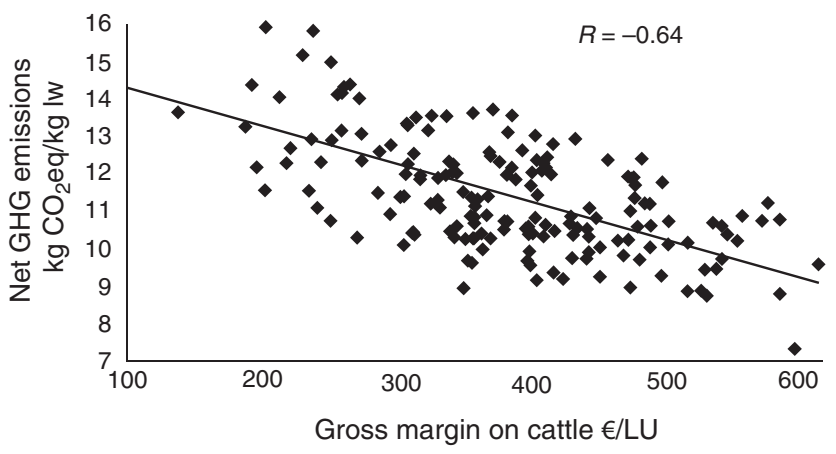

Fig. 4. Gross margin on cattle expressed in euros per livestock unit (LU) and net $\mathrm{GHG}$ emissions in $\mathrm{kg} \mathrm{CO}$ eq $/ \mathrm{kg} \mathrm{kg}$ liveweight produced.

\section{Future research priorities}

On the basis of the previous examples, more and more authors have suggested extending the concept of beef quality not only to cover all characteristics of the product itself (e.g. in terms of tenderness, palatability, nutritional value, safety) but also to cover all extrinsic qualities more or less associated with beef (such as e.g. livestock practices, animal welfare, carbon footprint, price for consumers, income for producers) (for review, see Hocquette et al. 2012b). A special focus has to be made on environmental issues due to the negative perception of beef production associated with GHG emissions. Therefore, Scollan et al. (2011) have suggested establishing an environmental index to combine carbon footprint, water and energy use for beef production. Soil acidification, plant biodiversity in pasture, and other environmental criteria can be added in this potential environmental index. Once established, this environmental index has to be combined with a beef palatability index (similar to the quality score provided by the MSA system), a nutritional value index (e.g. combining, for instance, iron content, fatty acid profile), an economic index (combining, for instance, a good price for consumers, reasonable incomes for producers and reasonable margins for distributors), and any other issues important for consumers and supply chain participants (Fig. 5).

Improving beef sustainability by enhancing the different components of extrinsic quality, and especially the environmental friendliness, is a major challenge. At first it is necessary to take the right indicators and numbers. A well known example is that of water use. It is frequently stated that $1 \mathrm{~kg}$ beef requires $15000 \mathrm{~L}$ water for its production, but this value corresponds for almost $95 \%$ to 'green' water, i.e. water that is necessary for crop or herbage growing, and which should be 'used' even if land is free of animals. There is no correspondence between this calculation and water scarcity, which can be calculated from effective water withdrawals from rivers or aquifers (Doreau et al. 2012), and so effective water consumption for beef production is not a major source of water scarcity. However, GHG emissions per kilogram of meat are higher for beef than for pork and chicken (de Vries and de Boer 2010). Mitigation techniques have been extensively explored (Hristov et al. 2013), but they are not easy to implement for beef production because most emissions come from the cow-calf herd before fattening, as stated above, and because the major part comes from methane, which roughly depends on total feed intake required for producing meat (Veysset et al. 2010). Explorations of various improvements of the feeding and management of beef production have been made for Canadian and French systems (Beauchemin et al. 2011; Nguyen et al. 2013). These studies draw similar conclusions: a significant reduction of emissions is possible only when several techniques are used simultaneously. When these techniques require fewer areas for the same production, the released land can be used for additional production, or for carbon storage (for example, as forests). In theory, producing beef from the dairy herd may decrease GHG emissions, because emissions of the dairy herd are shared between milk and beef production. However, this possibility is limited by the reduction of the dairy herd due to more efficient dairy cows that produce more milk per cow but 


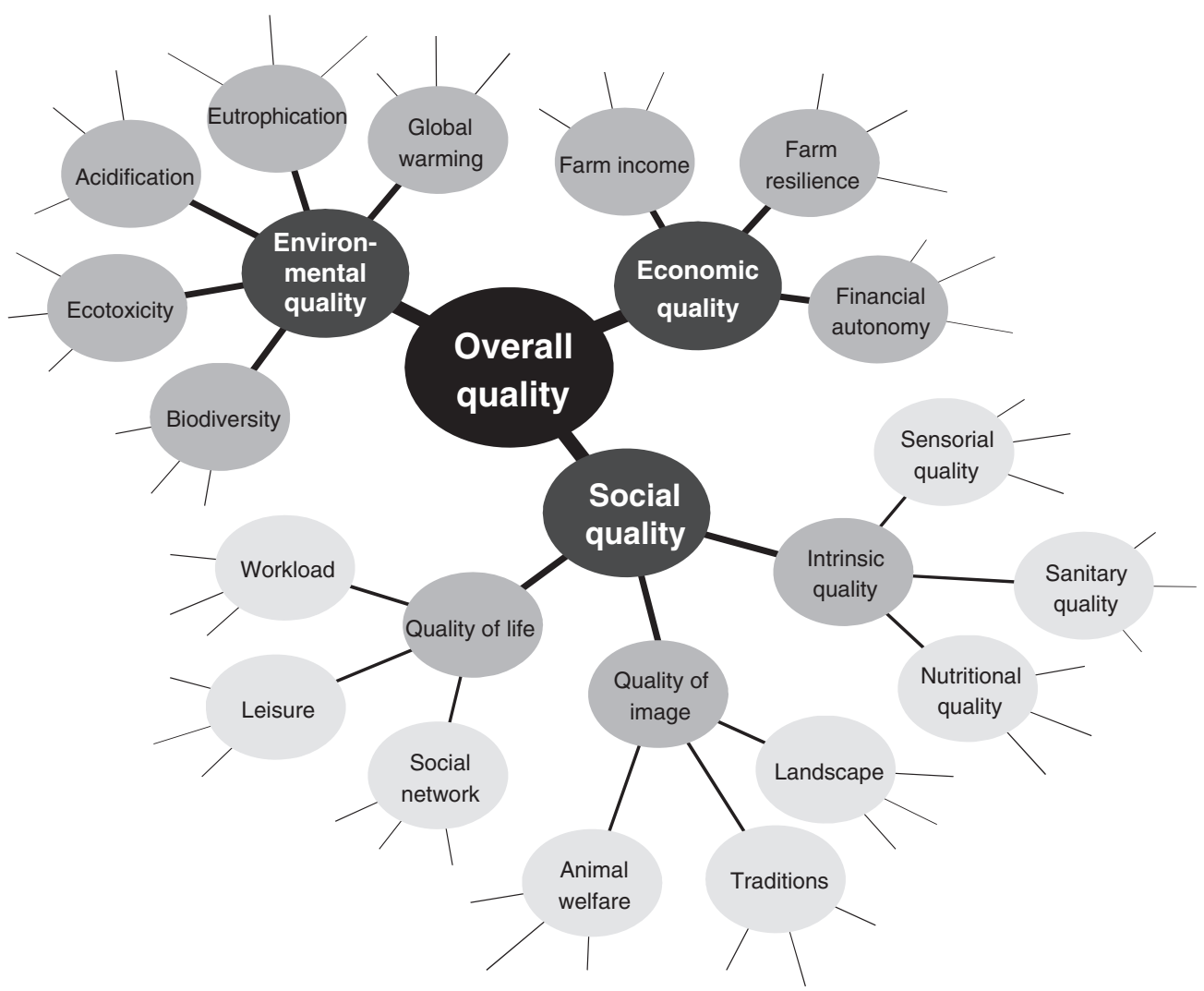

Fig. 5. Combination of intrinsic and extrinsic quality traits of beef for better sustainability of the whole beef supply chain.

not more beef. In the end, it is a trade-off worth having. For example, as discussed before, converting cellulose into meat from semimarginal lands may be considered as a tolerable GHG emission.

In northern Europe, a Sustainability Index was developed as a dynamic prototype. It is based on indicators for the evaluation of sustainability. Data from farms in Denmark and Sweden were collected and registered online in an existing tool 'AnalysePlatformen' (www.analyseplatformen.dk). The choice of indicators is crucial. A good indicator must be (1) based on generally accepted biological relations, (2) understandable and acceptable for stakeholders, and (3) reflect the actions of the farmer. The indicators that are registered in this prototype are related to animal welfare, climate change, use of resources, animal impact, biodiversity, social responsibility, and economy (Munk et al. 2013). In addition to the issue of indicator selection, the question of the aggregation of these indicators up to an overall assessment is also crucial: how can we combine pears and apples? This leads to issues on relative importance to be assigned to the different indicators and on compensations (should they be forbidden, limited, or even fully authorised as done when using a weighted sum?).

More generally, different authors or research groups have speculated about what future research priorities should be for the beef sector in order to satisfy the increasing number of wishes of consumers and citizens, which means a very broad concept of quality including all these wishes. Many experts observe that, in fact, there is likely to be a trend for intensification in many parts of the World beef supply chain for reasons associated with economic efficiency and the need to produce more animal protein to feed a hungry word. This trend is in tension with other more traditional, more ecological or more sustainable views.

According to Dumont et al. (2013), to better protect the environment in the future, animal production systems must take into account the principles of agroecological thinking based either on agroecology (which is based on stimulating natural processes to reduce inputs) or on industrial ecology (which is based on reducing demand for raw materials, lowering pollution, and saving on waste treatment). These principles include adopting new management practices aiming to improve animal health, decrease inputs for production, decrease pollution, increase diversity and resilience within animal production systems and preserve biological diversity. The question is how these principles could be combined to generate sustainable animal production systems that include environmental, social and economic performances together. This looks feasible since economy of inputs and reduction of pollution are present in most ecology-based animal production systems (reviewed by Dumont et al. 2013).

From a broader perspective, the 'Animal Task Force' group (which is made up of the major research providers and industryrepresentative bodies in Europe) have identified four areas for research and innovation contributing to a 'better society' and 
'competitive industries' in animal production. The first priority is resource efficiency with two main objectives: the efficiency of the use of resources by farm animals must increase (this means more efficient animals and farming systems) and the way we produce resources should be more efficient as well. This will induce both lower environmental footprints and satisfaction of the increasing demand for animal products. The second priority is healthy farm animals to ensure healthy consumers of meat and dairy products. The third priority is to develop animal production systems that simultaneously meet societal expectations for environmental control, human health and animal welfare. The fourth priority is knowledge exchange towards innovation (Animal Task Force 2013). Clearly, in this view, the 'Animal Task Force' group recommends to take into account the full range of livestock production systems (including multifunctional approaches, or more sustainable intensification of food production) and to develop multicriteria approaches in order to reach these priorities and to promote responsible livestock farming systems.

Herrero and Thornton (2013) mostly agreed with this view even if they presented it in a different way, but insisted on the fact that the livestock sector cannot be studied in isolation. This is especially true for the beef sector, which cannot be studied alone while ignoring the dairy sector or ignoring other meat sectors (pork and poultry production, for instance). More generally, the livestock sector has to be studied in connection with the whole food sector due to its social, environmental or economic connectedness with other food systems (Herrero and Thornton 2013).

In conclusion, we have speculated in this review for the need to combine indicators or predictors of both intrinsic qualities (the characteristics of the product itself, mainly tenderness and palatability, which are very important at the consumer level) and extrinsic qualities (such as e.g. animal health and welfare, carbon footprint, price) of beef, which are becoming more and more important for consumers. The Meat Standards Australia grading scheme combined with knowledge in muscle biochemistry and genomics are on the way to better predict sensory quality for the consumer. Extending aggregation of traits related to extrinsic quality or of their indicators is also a good starting point to reach a whole assessment of beef sustainability. This research strategy will help considerably in identifying win-win strategies that optimise different quality traits, some examples having been illustrated in this review. In this respect, most attention has been focussed on the environmental impacts of the beef sector. In all these analyses, using the correct metrics is essential. In this strategy, it is also important to better know interactions of the beef sector with other food sectors and other human activities. A further step of integration is thus the assessment of interconnections of the beef sector with other relevant sectors, and this also requires a multicriteria approach.

\section{References}

Allais S, Journaux L, Levéziel H, Payet-Duprat N, Raynaud P, Hocquette JF, Lepetit J, Rousset S, Denoyelle C, Bernard-Capel C, Renand G (2011) Effects of polymorphisms in the calpastatin and $\mu$-calpain genes on meat tenderness in 3 French beef breeds. Journal of Animal Science 89, 1-11. doi:10.2527/jas.2010-3063
Animal Task Force (2013) 'Research \& innovation for a sustainable livestock sector in Europe.' Available at http://www.animaltaskforce.eu/Portals/0/ ATF/documents $\% 20$ for $\% 20$ scare/ATF\%20white $\% 20$ paper\%20Research $\% 20$ priorities $\% 20$ for $\% 20 \mathrm{a} \% 20$ sustainable $\% 20$ livestock $\% 20$ sector $\% 20$ in \%20Europe.pdf [Verified 8 July 2014]

Beauchemin KA, Janzen HH, Little SM, McAllister TA, McGinn SM (2011) Mitigation of greenhouse gas emissions from beef production in western Canada - evaluation using farm-based life cycle assessment. Animal Feed Science and Technology 166-167, 663-677. doi:10.1016/j.anifeedsci. 2011.04.047

Bjarnadottir SG, Hollung K, Hoy M, Bendixen E, Codrea MC, Veiseth-KentE (2012) Changes in protein abundance between tender and tough meat from bovine longissimus thoracis muscle assessed by isobaric tag for relative and absolute quantitation (iTRAQ) and 2-dimensional gel electrophoresis analysis. Journal of Animal Science 90, 2035-2043. doi:10.2527/jas. 2011-4721

Bochu JL (2002). PLANETE: Méthode pour l'analyse énergétique de l'exploitation agricole et l'évaluation de gaz à effet de serre. In 'Proceedings of the symposium: quels diagnostics pour quelles actions agro-environnementales?' pp. 68-80. (Ed. Solagro) Toulouse, France. Available at http://reseau-lyceen.educagri.fr/wp-content/uploads/2011/ 05/planeteooct021.pdf [Verified 8 July 2014]

Bonny SPF, Legrand I, Polkinghorne RJ, Gardner GE, Pethick DW, Hocquette JF (2013) The EUROP carcase grading system does not predict the eating quality of beef. In 'Proceedings of the 64th annual meeting of the European Association for Animal Production’. p. 196. (Wageningen Academic Publishers: Wageningen, The Netherlands)

Bourguet C, Deiss V, Gobert M, Durand D, Boissy A, Terlouw EMC (2010) Characterising the emotional reactivity of cows to understand and predict their stress reactions to the slaughter procedure. Applied Animal Behaviour Science 125, 9-21. doi:10.1016/j.applanim.2010.03.008

Cassar-Malek I, Picard B, Bernard C, Hocquette JF (2008) Application of gene expression studies in livestock production systems: a European perspective. Australian Journal of Experimental Agriculture 48, 701-710. doi:10.1071/EA08018

Chriki S, Renand G, Picard B, Micol D, Journaux L, Hocquette JF (2013) Meta-analysis of the relationships between beef tenderness and muscle characteristics. Livestock Science 155, 424-434. doi:10.1016/ j.livsci.2013.04.009

Craigie CR, Navajas EA, Purchas RW, Maltin CA, Bunger L, Hoskin SO, Ross DW, Morris ST, Roehe R (2012) A review of the development and use of video image analysis (VIA) for beef carcass evaluation as an alternative to the current EUROP system and other subjective systems. Meat Science 92, 307-318. doi:10.1016/j.meatsci.2012.05.028

de Vries M, de Boer IJM (2010) Comparing environmental impacts for livestock products: a review of life cycle assessments Livestock Science 128, 1-11. doi:10.1016/j.livsci.2009.11.007

Doreau M, Bauchart D, Chilliard Y (2011) Enhancing fatty acid composition of milk and meat through animal feeding. Animal Production Science 51, 19-29. doi:10.1071/AN10043

Doreau M, Corson MS, Wiedemann SG (2012) Animal frontiers water use in livestock: a global perspective for a regional issue? Animal Frontiers 2 , 9-16. doi:10.2527/af.2012-0036

Doreau M, Makkar HPS, Lecomte P (2013) The contribution of animal production to agricultural sustainability. In 'Proceedings of the 4th international symposium on energy and protein nutrition and metabolism (ISEP): energy and protein metabolism and nutrition in sustainable animal production'. (Eds JW Oltjen, E Kebreab, H Lapierre) pp. 475-485. (Wageningen Academic Publishers: Wageningen, The Netherlands)

Dumont B, Tallowin JRB (2011) Interactions between grassland management and species diversity. In 'Grassland productivity and ecosystem services'. (Eds G Lemaire, J Hodgson, A Chabbi) pp. 129-137. (CAB International, Wallingford, UK) 
Dumont B, Fortun-Lamothe L, Jouven M, Thomas M, Tichit M (2013) Prospects from agroecology and industrial ecology for animal production in the 21 st century. Animal 7, 1028-1043. doi:10.1017/S17 51731112002418

Eugène M, Martin C, Mialon MM, Krauss D, Renand G, Doreau M (2011) Dietary linseed and starch supplementation decreases methane production of fattening bulls. Animal Feed Science and Technology 166-167, 330-337. doi:10.1016/j.anifeedsci.2011.04.023

Farruggia A, Martin B, Baumont R, Prache S, Doreau M, Hoste H, Durand D (2008) Quels intérêts de la diversité floristique des prairies permanentes pour les ruminants et les produits animaux? Productions Animales 21 , 181-200.

Gruber SL, Tatum JD, Engle TE, Chapman PL, Belk KE, Smith GC (2010) Relationships of behavioral and physiological symptons of preslaughter stress to beef longissimus muscle tenderness. Journal of Animal Science 88, 1148-1159. doi:10.2527/jas.2009-2183

Guignot F, Quilichini Y, Renerre M, Lacourt A, Monin G (1992) Relationships between muscle type and some traits influencing veal colour. Journal of the Science of Food and Agriculture 58, 523-529. doi:10.1002/jsfa.2740580411

Guillemin N, Bonnet M, Jurie C, Picard B (2011) Functional analysis of beef tenderness. Journal of Proteomics 75, 352-365. doi:10.1016/ j.jprot.2011.07.026

Herrero M, Thornton PK (2013) Livestock and global change: emerging issues for sustainable food systems. Proceedings of the National Academy of Sciences of the United States of America 110 20 878-20 881. doi:10.1073/pnas.1321844111

Hocquette JF, Boichard D, Cassar-Malek I, Laville E, Renand G, Levéziel H, Picard B (2008) Functional and positional genomics in beef cattle: current programs and potential progress. Sciences des Aliments $\mathbf{2 8}$ 335-350. doi:10.3166/sda.28.335-350

Hocquette JF, Bernard-Capel C, Vidal V, Jesson B, Levéziel H, Renand G, Cassar-Malek I (2012a) The GENOTEND chip: a new tool to analyse gene expression in muscles of beef cattle for beef quality prediction. $B M C$ Veterinary Research 8, 135. doi:10.1186/1746-6148-8-135

Hocquette JF, Botreau R, Picard B, Jacquet A, Pethick DW, Scollan ND (2012b) Opportunities for predicting and manipulating beef quality. Meat Science 92, 197-209. doi:10.1016/j.meatsci.2012.04.007

Hocquette JF, Capel C, David V, Guéméné D, Bidanel J, Ponsart C, Gastinel PL, Le Bail PY, Monget P, Mormède P, Barbezant M, Guillou F, Peyraud JL (2012c) Objectives and applications of phenotyping network set-up for livestock. Animal Science Journal 83, 517-528. doi:10.1111/j.17400929.2012.01015.x

Hocquette JF, Van Wezemael L, Chriki S, Legrand I, Verbeke W, Farmer L, Scollan ND, Polkinghorne R, Rødbotten R, Allen P, Pethick DW (2014) Modelling of beef sensory quality for a better prediction of palatability. Meat Science 97, 316-322. doi:10.1016/j.meatsci.2013.07. 031

Hristov AN, Ott T, Tricarico J, Rotz A, Waghorn G, Adesogan A, Dijkstra J, Montes F, Oh J, Kebreab E, Oosting SJ, Gerber PJ, Henderson B, Makkar HPS, Firkins JL (2013) Mitigation of methane and nitrous oxide emissions from animal operations: III. A review of animal management mitigation options. Journal of Animal Science 91, 5095-5113. doi:10.2527/jas.2013-6585

Juárez M, Basarab JA, Baron VS, Valera M, Larsen IL, Aalhus JL (2012) Quantifying the relative contribution of ante- and post-mortem factors to the variability in beef texture. Animal 6, 1878-1887. doi:10.1017/ S1751731112000572

Legrand I, Hocquette J-F, Polkinghorne RJ, Pethick DW (2013) Prediction of beef eating quality in France using the Meat Standards Australia system. Animal 7, 524-529. doi:10.1017/S1751731112001553

Mialon MM, Lherm M, Micol D, Doreau M, Martin C (2013) Improving animal welfare and economic sustainability in fattening bulls systems in France: a comparison of three different feeding programs. In 'Enhancing animal welfare and farmer income through strategic animal feeding'. (Ed. HPS Makkar) pp. 27-35. (FAO: Rome)

Mortimer SI, van der Werf JHJ, Jacob RH, Pannier L, Pethick DW, Pearce KL, Warner RD, Geesink GH, Edwards JEH, Ponnampalam EN, Ball AJ, Gilmour AR, Hopkins DL (2014) Genetic parameters for meat quality traits of Australian lamb meat. Meat Science 96, 1016-1024. doi:10.1016/ j.meatsci.2013.09.007

Munk A, Søndergaard E, Kristensen T, Mogensen L, Nielsen NI, Trinderup M, Petersen RS, Bligaard HB (2013) Sustainability index for beef production in Denmark and Sweden. In 'Proceedings of the 64th Annual Meeting of the European Association for Animal Production'. p. 194. (Wageningen Academic Publishers: Wageningen, The Netherlands)

Nguyen TTH, van der Werf HMG, Eugène M, Veysset P, Devun J, Chesneau G, Doreau M (2012) Effect of type of ration and allocation methods on the environmental impacts of beef-production systems. Livestock Science 145, 239-251. doi:10.1016/j.livsci.2012.02.010

Nguyen TTH, Doreau M, Eugène M, Corson MS, Garcia-Launay F, Chesneau G, van der Werf HMG (2013) Effect of farming practices for greenhouse gas mitigation and subsequent alternative land-use on environmental impacts of beef-cattle production systems. Animal 7, 860-869. doi:10.1017/S1751731112002200

Normand J, Rubat E, Evrat-Georgel C, Turin F, Denoyelle C (2009) "National" beef tenderness survey. Rencontres Recherches Ruminants 16, $147-150$.

Ouali A, Gagaoua M, Boudida Y, Becila S, Boudjellal A, Herrera-Mendez $\mathrm{CH}$, Sentandreu MA (2013) Biomarkers of meat tenderness: present knowledge and perspectives in regards to our current understanding of the mechanisms involved. Meat Science 95, 854-870. doi:10.1016/ j.meatsci.2013.05.010

Pethick DW, Ball AJ, Banks RG, Hocquette JF (2011) Current and future issues facing red meat quality in a competitive market and how to manage continuous improvement. Animal Production Science 51, 13-18. doi:10.1071/AN10041

Peyraud JL (2011) Economic dimension and environmental impact of beef production in France. Dimension économique et impact environnemental de la production de viande bovine en France. Bulletin de L'Académie Nationale de Médecine 195, 1813-1825.

Picard B, Cassar-Malek I, Guillemin N, Bonnet M (2011) Animal systems quest for novel muscle pathway biomarkers by proteomics in beef production. In 'Comprehensive biotechnology, vol. 4'. 2nd edn. (Ed. M Moo-Young) pp. 395-405. (Elsevier: Amsterdam)

Picard B, Lefèvre F, Lebret B (2012) Meat and fish flesh quality improvement with proteomic applications. Animal Frontiers 2, 18-25. doi:10.2527 af.2012-0058

Polkinghorne RJ, Thompson JM (2010) Meat standards and grading: a world view. Meat Science 86, 227-235. doi:10.1016/j.meatsci.2010.05.010

Reverter A, Johnston DJ, Ferguson DM, Perry D, Goddard ME, Burrow HM, Oddy VH, Thompson JM, Bindon BM (2003) Genetic and phenotypic characterization of animal, carcass, and meat quality traits from temperate and tropically adapted beef breeds. 4. Correlations among animal, carcass, and meat quality traits. Australian Journal of Agricultural Research 54, 149-158. doi:10.1071/AR02088

Scollan ND, Greenwood PL, Newbold CJ, Yáñez Ruiz DR, Shingfield KJ, Wallace RJ, Hocquette JF (2011) Future research priorities for animal production in a changing world. Animal Production Science 51, 1-5. doi:10.1071/AN10051

Soussana JF, Tallec T, Blanfort V (2010) Mitigating the greenhouse gas balance of ruminant production systems through carbon sequestration in grasslands. Animal 4, 334-350. doi:10.1017/S1751731109990784

Terlouw EMC, Bourguet C, Deiss V (2012) Stress at slaughter in cattle: role of reactivity profile and environmental factors. Animal Welfare (South Mimms, England) 21, 43-49. doi:10.7120/096272812X1335370059 3482 
Thompson JM (2002) Managing meat tenderness. Meat Science 60, 365-369.

Troy DJ, Kerry JP (2010) Consumer perception and the role of science in the meat industry. Meat Science 86, 214-226. doi:10.1016/j.meatsci. 2010.05.009

Verbeke W, VanWezemael L, de Barcellos MD, Kügler JO, Hocquette JF, Ueland Ø, Grunert KG (2010) European beef consumers' interest in a beef eating-quality guarantee: insights from a qualitative study in four EU countries. Appetite 54, 289-296. doi:10.1016/j.appet.2009.11.013

Veysset P, Lherm M, Bebin D (2010) Energy consumption, greenhouse gas emissions and economic performance assessments in French Charolais suckler cattle farms: model-based analysis and forecasts. Agricultural Systems 103, 41-50. doi:10.1016/j.agsy.2009.08.005

Veysset P, Lherm M, Bébin D, Roulenc M, Benoit M (2014) Variability in greenhouse gas emissions, fossil energy consumption and farm economics in suckler beef production: analysis of results from 59 French farms. Agriculture, Ecosystems \& Environment 188, 180-191. doi:10.1016/ j.agee.2014.03.003

Warner RD, Ferguson DM, Cottrell JJ, Knee BW (2007) Acute stress induced by the preslaughter use of electric prodders causes tougher beef meat. Australian Journal of Experimental Agriculture 47, 782-788. doi:10. 1071/EA05155 